\title{
Philosophy
}

\section{National Identity - A Multiculturalist's Approach}

\section{Varun Uberoi}

To cite this article: Varun Uberoi (2018) National Identity - A Multiculturalist's Approach, Critical Review of International Social and Political Philosophy, 21:1, 46-64, DOI: $10.1080 / 13698230.2017 .1398475$

To link to this article: https://doi.org/10.1080/13698230.2017.1398475
(c) 2017 The Author(s). Published by Informa UK Limited, trading as Taylor \& Francis Group

Published online: 15 Nov 2017.

Submit your article to this journal \lceil

Џll Article views: 2343

View Crossmark data $\nearrow$ 


\title{
๖ OPEN ACCESS Check for updates
}

\section{National Identity - A Multiculturalist's Approach}

\author{
Varun Uberoi \\ Department of Social and Political Sciences, Brunel University, London, UK
}

\begin{abstract}
'Multiculturalists' in Britain have advocated the importance of national identity since the 1970s, yet we know very little about the ways in which they do so. In this article, I will examine how one of Britain's most prominent multiculturalists, Bhikhu Parekh, has advocated the importance of national identity since the 1970s. I will show that Parekh's way of thinking about national identity is distinct from the ways in which other prominent thinkers discuss such an identity, and valuable, as Parekh has insights into what such an identity is and why we should value it. This article will thus identify a previously unnoticed, distinct and valuable way of thinking about national identity, which comes from a multiculturalist in Britain.
\end{abstract}

KEYWORDS Multiculturalism; national identity; Bhikhu Parekh; liberal nationalism

Those in Britain who show why cultural diversity and intercultural dialogue are valuable and who advocate government policies that promote Britain's multicultural nature are often called 'multiculturalists' (Modood, 2014, p. 31). Such multiculturalists are often said to ignore the importance of national identity (Barry, 2001, p. 77; Goodhart, 2013, p. 201) even though multiculturalists in Britain have advocated its importance since the 1970s (Parekh, 1974, p. 230; Modood, 1992, p. 24). Yet we know very little about the ways in which multiculturalists in Britain advocate the importance of national identity and in this article I will examine how one of Britain's most prominent multiculturalists, Bhikhu Parekh, has done so since the 1970s. I will show that Parekh thinks about the nature and worth of national identity in a way that is distinct from the ways in which other prominent thinkers do so; and that is also valuable, as Parekh has insights into what such an identity is and why we should value it.

Parekh began to write about national identity in the 1970s when mass immigration, minority nationalism and membership of the European Economic Community were altering Britain. People were beginning to ask what Britain was, whether British people have ever had 'a way of life', and, if so, whether immigrants were altering it. Such questions provoked sustained thought by Parekh

CONTACT Varun Uberoi Varun.Uberoi@brunel.ac.uk

(c) 2017 The Author(s). Published by Informa UK Limited, trading as Taylor \& Francis Group.

This is an Open Access article distributed under the terms of the Creative Commons Attribution License (http:// creativecommons.org/licenses/by/4.0/), which permits unrestricted use, distribution, and reproduction in any medium, provided the original work is properly cited. 
about the topic of national identity for 40 years. Yet neither political theorists who advocate the value of national identity (Miller, 1995, 2001; Tamir, 1993), nor political theorists who deny such value (Abizadeh, 2002; Mason, 2012) usually discuss Parekh's work on this topic. For sure, some scholars criticise one or two texts in which Parekh discussed national identity (Canovan, 1996, p. 84; Modood, 2001, p. 249; Yack 2012, p. 28). Yet even these scholars do not show, as I will, that Parekh developed a distinct and valuable way of thinking about the nature and worth of national identity in many texts over four decades.

Many may have missed Parekh's work on this subject for three reasons. First, many in Britain assume that multiculturalists do not advocate the importance of national identity. Some may thus assume that a prominent multiculturalist like Parekh also does not. Second, Parekh devotes limited attention to the topic of national identity in well-known books like Rethinking Multiculturalism, thus some may assume that he devotes limited attention to this topic elsewhere. Third, Parekh's ideas about this topic are often in less well-known book chapters, review essays, pamphlets and published lectures that few would know to look for. Yet I will show that these texts contain a distinct and valuable way of thinking about national identity.

But I will only outline Parekh's way of thinking about national identity as ideally I would say more about which thinkers influenced his ideas on this topic and the context in which his ideas on this topic emerged. I would also ideally examine how historically novel Parekh's way of thinking about such an identity is by comparing it, for example, to how Plato and Aristotle discussed the identity of a polity and David Hume, Ernest Barker and others discussed 'national character'. Yet discussing such subjects would require a lengthier study that would only seem justified if I could first show that there is something distinct and valuable in Parekh's texts relating to national identity. I show below why I think there is.

However, there is a difficulty attached to Parekh's ideas on this subject being in his less well-known book chapters, pamphlets, review articles and published lectures. The difficulty is that these texts are not like peer-reviewed journal articles or monographs, as they contain ideas and arguments that Parekh was'trying out' and that provoke thought but are, at times, unclear. It is therefore necessary to interpret these texts to clarify the nature and significance of the ideas and arguments in them or these ideas and arguments could just be ignored or deemed implausible. Thus, I clarify Parekh's ideas and arguments using my own terms, examples and arguments just as Parekh (1981, p. iv, 1982, p. ii) and others (Cohen, 1979) do in their work on other thinkers. Parekh's texts guide what I will say. Yet I will improve the clarity of the ideas and arguments in them so as to show their significance when compared with those of other prominent thinkers who discuss the nature and worth of national identity. But who exactly are these other prominent thinkers?

There is little need to compare Parekh's ideas about national identity with the ideas of thinkers who are focusing on something else. Hence, the other thinkers 
are not Isaiah Berlin (2003), Elie Kedourie (1998) or Ernest Gellner (1983), who all trace the origins of 'nationalism' in different ways, but say little to specify exactly what national identity is or why we should value such an identity. Nor am I referring to Jürgen Habermas (1998, p. 219) or Jan Werner Müller (2007, p. 63), who also say little about what national identity is or why we should value it and instead depict and defend what they call 'post-national' ideas. ${ }^{1}$

The prominent thinkers that I am referring to are similar to Parekh as they discuss, at length, both what national identity is and why we should value it. These thinkers are those such as David Miller (1995), Will Kymlicka (1995) and Yael Tamir (1993), who are often known as 'liberal nationalists,'2 and those such as Roger Scruton $(1990,2006)$ who are often known as 'conservative nationalists' (Crowder, 2013, pp. 83-84). Yet these two types of nationalist thinkers discuss the same subject as Parekh so differently that distinguishing their ideas from his requires no detailed exegesis of conservative and liberal nationalist works. And as these nationalist thinkers are prominent, they require only the following short introduction.

These thinkers refer to themselves as either liberals or conservatives and these traditions of thought shape their ideas of nationhood. For example, Burke's (1996, p. 572) idea of polities being a 'partnership' between the living, the dead and the unborn shapes what a conservative such as Scruton claims nations are. Scruton (1990, p. 305) thus depicts a nation as a group of people who share not only territory and history, but descent and a culture bequeathed from one generation to the next, all of which makes its members seem 'familiar' to one another. This idea of nationhood is then used in Scruton's (2006, p. 25) conservative 'doctrine' so as to argue that a nation must have its own state so as to protect the familiarity that its members experience from 'threats' such as immigration. And as Scruton argues that nations should have their own states, he is a conservative who advocates a form of what is often called 'nationalism' (Gellner, 1983, p. 1; Kedourie, 1998, p. 67), thus he is often called a conservative nationalist.

Similarly, the liberal ideal that comes from Kant (1929, p. 335), J. S. Mill (1991, p. 65) and others, of an individual choosing his life 'plan for himself', shapes how liberal nationalists think of nations. This is because if individual choice is important to liberals, then nations that are constituted by 'consent' or a 'desire to live a common life', as Ernest Renan argued (2001, p. 175 emphasis added), should be unproblematic for liberals. Liberal nationalists thus endorse Renan's ideas in their respective forms of liberalism and they argue that individuals need the norms, values and beliefs of a national culture to make choices. A national culture should thus be valuable to liberals and should be protected by nations having their own states or at least some form of 'self-rule' (Miller, 1995, pp. 85-88; Tamir, 1993, p. 66). And by advocating such 'self-rule' for nations, these liberal thinkers are advocating a form of nationalism (Gellner, 1983, p. 1; Kedourie, 1998, p. 67) thus they are often called liberal nationalists. 
I thus briefly consider the ideas of conservative and liberal nationalists alongside Parekh's, first to distinguish Parekh's ideas about what national identity is and second to distinguish his ideas about why such an identity is valuable. Third, I discuss potential criticisms and I conclude by noting three implications of Parekh's way of thinking about national identity.

\section{What is national identity?}

Parekh $(1974$, p. 231,2008, p. 56) notes how we think and talk about national identity in at least two ways: first as, for example, a person's 'English', 'British', 'American' or'French' identity, and second as England, Britain, America or France's identity. Conservative and liberal nationalists do not distinguish between the two. Such nationalist thinkers also claim that national identity is a type of identity but they do not say what identity is (Scruton, 2006, p. 26; Miller, 1995, p. 21). Yet by clarifying what identity is we also clarify the type of entity that national identity is in the two senses above. Hence, Parekh (1995, p. 255, 2000a, p. 5) often begins to clarify what national identity is by first clarifying what identity is, as will I in the following way.

It would be rare and strange to ask about the 'identity' of a vegetable, or a table, or a garden. We might ask what these things are but we seldom use the term 'identity' when we do, as this term is often reserved for human beings. We thus ask about the identity of a person or of the racial, religious, and other groups that people comprise and when we do, we are asking what they are. When we know what two people or two groups of people are, we can more easily distinguish between them. Likewise, their differences can help to show what each of them is. Yet either way, their differences are logically distinct from their identity. And if we ask about a person's identity we are seldom today asking about their 'soul' or their 'hidden self'.

Instead, we are usually asking one of two things about a person. First, we might be asking about a person's 'overall identity' and what this person is as a whole (Parekh, 2008, p. 9). This is difficult to know, as self-reflection can entail questions that may be too painful, time consuming or complex to answer and it seldom prevents us surprising ourselves and others. Likewise, what a person is changes over time - hence old philosophical debates about whether a person's identity remains the same over their life despite the ways in which they change during it (Parfit, 1987; Sorabji, 2006). Of course we know parts of what we are, and thus a person might say that being a Muslim, a man or an artist are all part of his identity. But it still remains unclear how to interpret and relate these parts of what we are so as to discern what we are as a whole. Thus, what we are as a whole usually remains unclear to us.

Parts of us are also referred to as our racial, religious, sexual and other 'identities'. This is the second way in which we might ask about a person's identity. And we usually only refer to aspects of ourselves that we think help to make 
us the person we are, as 'identities'. Thus, few would include being a commuter or a user of shampoo among their identities but many might say that being a Muslim, a man or an artist are among their identities.

With the above in mind, a man who refers to his 'English' or 'British' identity is not referring to his 'overall identity' as he may also think of himself as a father. Instead, he is referring to part of his identity or one of his identities, and either way he is referring to part of what he thinks he is. Likewise, a man who refers to his English or British identity is not only saying that he is part of England or Britain. He is also saying that England or Britain shapes what he is thus he may also say that he is English or that he is British, and he may discuss 'his Englishness' or 'his Britishness' too. A person with a national identity thus usually thinks that he is part of, and shaped by, entities such as England or Britain. But what are entities such as England and Britain, and why do people feel part of and shaped by them?

An entity such as England is like Scotland and Wales and can be thought of as a nation: a territorially concentrated group of people who typically not only value their territory but share a history and a culture too. This culture consists of beliefs, norms and values, and it is shared by people not as they share resources, by dividing them, but as people share a home. This is because when certain beliefs, norms and values are ubiquitous among a territorially concentrated group, these beliefs, norms and values surround them and create a space in which they can feel safe and at ease, just as a home can. A person may thus feel part of a nation as he feels safe and at ease among its members, and shaped by a nation as he senses when he is abroad, that it influences where and among whom he feels safe and at ease.

An entity such as Britain is like America or France, and need not be a nation in the above sense as the people of such an entity may or may not share a culture in the way that I describe. Instead, an entity such as Britain is a nation in the sense that all members of the United Nations are, and this suggests that what we have in mind is an 'independent state' or what Parekh (1996, p. 262), at times, call 'a polity'. A polity is a territorially concentrated group of people who govern their own collective affairs using legal and political institutions, norms, values and beliefs, or what we might call'a political culture.' Only some polities are 'nations' in the way that England is. Yet a person can feel part of a polity as they are a citizen of it, and they can feel shaped by a polity as its legal, political and educational institutions can regulate their behaviour and influence their notions of what is 'acceptable' and 'normal'.

When a polity is not a nation in the way that England, for example is, its citizens are still often thought to have national identities just as they have'national laws','national policies' or 'national representatives' such as a prime minister. In such cases 'national' can imply a polity, not a nation. Thus, people's Indian and British identities are often called 'national identities' regardless of debates about whether their polities are 'really' nations (Parekh, 1994, p. 501). ${ }^{4}$ 
Of course, a person can also feel part of and shaped by a nation that is a polity. And a person can feel part of and shaped by entities such as England and Britain simultaneously so that they feel 'English' and 'British' and have more than one national identity. Thus, a person with a national identity typically feels part of and shaped by a nation or a polity, or both.

But if we ask about the identity of England, Scotland, Britain, America, and so on we are no longer asking about a person's national identity. Instead, we are asking about the identity of a territorially concentrated group of people that may be a nation or a polity or both. And when we refer, for example, to England's identity, we are referring to what the people of England are collectively, thus we do not focus on what we use to conceptualise them individually. Instead, we focus on what we use to conceptualise them as connected to one another so that we can think of them collectively, and as a group. This often occurs in the following ways.

We often conceptualise the members of a polity or a nation as being connected to one another by focusing on the territory that they share, or on what is common among many of them, such as a race, a religion or tendencies in thought and behaviour. We might also note the rights and duties that all members of a polity have in common, or the traditions of thought that they use to pursue collective goals and regulate their collective affairs. Or we might refer to what the members of a polity have in 'common ownership', such as political institutions. Such features allow us to provide'a more or less coherent conception' of what the members of a nation or a polity are (Parekh, 1994, p. 492). And when we refer to the identity of England, Britain, America, and so on, all we are referring to is a conception of a nation or a polity, or both.

People often have vague conceptions of their nation or polity and intellectuals and politicians often try to clarify such conceptions. In doing so, such intellectuals and politicians may offer an ideal of the polity or nation to live up to, or discuss how its members should guard themselves against certain tendencies in their own thoughts and behaviour. Yet such intellectuals and politicians interpret and relate a nation or a polity's features in different ways according to their own moral, political and other views, and thus the conceptions that they offer differ (Parekh, 2009, p.39). Other members of the polity or nation also generalise about their polity or nation using their differing daily experiences, and moral and political views. Thus, they too conceptualise their nation or polity in a range of different ways. Hence, only some in Britain call Britain a 'Christian country' and only some in America call it 'the land of the free'.

The two ways of thinking and talking about national identity are related as a person must use some conception of their polity or nation to know that they feel part of it and shaped by it, even if this conception is vague. And a person cannot plausibly say that they feel 'British' or 'English' without having any notion of Britain or England. Equally, the relationship between these two ways of thinking about national identity can be empirically significant. This is because if ethnic 
minorities in Britain think that British people are solely white and Christian, then such minorities might think it strange to think of themselves as British. And if many in England think that England is a white and Christian nation, they may think that ethnic minorities cannot be English. The conceptions of a polity or a nation that its members have can thus influence how they think about their own and one another's national identities.

To summarise, Parekh has three insights into what national identity is. First, we think and talk about national identity in at least two ways. Thus we might refer, for example, to England, Britain's or America's identity, and also to a person's English, British or American identity. Second, both ways of thinking and talking about national identity are related. Third, in both cases we are always referring to an identity, but not necessarily to a nation. Liberal and conservative nationalists do not offer these insights. Thus, when they discuss national identity we might ask if they are referring to the identity of a person, a polity or a nation, to all of them, or to none of them, as it can be unclear (Kymlicka, 1995, pp. 52-53; Scruton, 2014, p. 36). We might also ask such nationalist thinkers in what sense are any of the above identities and whether ideas of national identity and nation are as connected they often claim (Miller, 1995, p. 17; Scruton, 2006, p. 15). Parekh's insights show us how we might begin to question the ways in which these nationalist thinkers often discuss national identity. But Parekh also has an important insight into why we should value national identity that I will now discuss.

\section{Valuing national identity}

Parekh (2008, p. 56) notes how a national identity can be important to a person who may think, for example, that being 'English' or 'British' is important to them. And such an identity can be important for a person, as acknowledging how they are part of and shaped by a nation or a polity can aid their self-understanding. But the idea of national identity is also important for Parekh's understanding of multiculturalism, which is what I will focus on.

For Parekh, multiculturalism is not just a reference to the cultural diversity of a polity or to policies that declare a polity to be multicultural, as Canada has, or that permit multicultural education in schools. Instead, multiculturalism is a 'vision' of what such a diverse polity can become using, inter alia, such policies (Parekh, 1990, p. 68, 2000c, p. x)..$^{5}$ I explain this vision in detail elsewhere (Uberoi, 2015a). Yet as Parekh thinks that national identity can help to achieve part of this vision, a very brief understanding of the relevant part of this vision is needed here.

In this vision, Parekh shows how the values, beliefs and norms of different cultural groups in a polity illuminate different ways of thinking, realising values and satisfying needs that can be a source of intercultural learning in the polity (Parekh, 2000a, p. 167). Yet if members of a polity are to learn from their cultural 
differences they must fear these differences less than they often do, and they must interact with one another regardless of such differences. I will show how a particular type of national identity can help to achieve this while first helping to foster something that Parekh's polity, like any polity, needs: unity among its members.

Such unity is often simply the ability of members of a polity to assume that they are a unit or a group when, for example, they conceptualise collective goals and challenges that they can meet together. In difficult times, such as war, members of a polity may not need only to assume that they are a group, but also explicitly think of themselves as one, and be loyal to one another too. Thus, as with unity among family members, friends or co-religionists, unity among the members of a polity will often become more visible with need. National identity can help the members of a polity to assume and think that they are a unit or a group and to feel loyal to one another, and to illustrate this, note the following.

Those who, for example,'feel American' often think of themselves as a group just like those who share a religious identity, and are'Muslim', or a sexual identity, and are 'gay', can. They often feel loyal to their 'fellow Americans', and they can feel proud of one another's achievements because they assume that they are a group. Equally, those who claim that they 'feel American' must, we have seen, have conceptions of America that are often vague. Yet if these conceptions are clear they can help Americans to visualise themselves as a group. ${ }^{6}$

However, if the conceptions of a polity that are held by its members exclude cultural minorities, these conceptions can be divisive as they encourage such minorities to seem like 'outsiders' (Parekh 1974, p. 231). This can exacerbate the exclusion and discrimination that cultural minorities often experience and make such minorities unwilling to be part of a group that mistreats them. But if members of a polity have conceptions of their polity in which cultural minorities are normal and equal members of the polity, cultural minorities are less likely to be mistreated by such a group and they are also more likely to feel part of it.

Parekh thus advocates such inclusive conceptions of a polity so as to foster unity. And when cultural minorities are thought of as equal and normal members of the polity, their cultural differences are also less likely to seem abnormal to others in the polity. Such cultural differences are also thus less likely to be feared and to seem like something to avoid. Hence, interaction between members of the polity regardless of their cultural differences is more likely when members of a polity think of themselves as such an inclusive unit or group.

Inclusive conceptions of a polity thus help to foster (1) the unity that Parekh's multiculturalist polity needs simply because it is a polity, and (2) the unity that its members need to fear their cultural differences less than they often do and to interact regardless of these differences. Of course, Parekh cannot guarantee that people will, for example, 'feel British' and have such clear and inclusive conceptions of their polity. Yet he can show what a government should and should not do to encourage this, and consider first what a government should not do. 
No government can force people to think of themselves as, for example, 'British' without an 'unacceptable level of coercion' and perhaps not even then (Parekh, $2000 a$, p. 196). Equally, no government can promote a single conception of a polity without running the risk of this conception seeming like it is artificial and it is being imposed on those who think about their polity differently. Members of a polity will have different conceptions of their polity as they will interpret it using their own experiences and moral and political views, all of which vary.

But a government can use school curricula to teach children that they are part of a polity by discussing their rights and duties as its members. Children can also be taught that their polity is likely to shape them as its legal, political and educational institutions usually influence what members of the polity think is 'acceptable' and 'normal'. This influence affects so many in a polity that it can be hidden in plain sight, yet is often discernible when people go abroad. There people encounter ideas of what is 'normal' and 'acceptable' that differ from their own ideas and those in their polity and in doing so they often think that there is something, for example, 'British' about what they are. To encourage this thought, children can go on foreign exchange schemes and study beliefs and practices that are'acceptable' and 'normal'in other polities. Hence, the type of education that can encourage children to think that there is something, for example, 'British' about what they are need not be nationalistic, nationalist or national. Instead, it can be a type of international education that can also be used to teach children that what is 'acceptable' and 'normal' in their polity need not be inevitable or best.

A government can also accept that features of a polity are interpreted and related in different ways by citizens who thus have different conceptions of the polity that children can learn about, choose from and develop. High school curricula can aid this by ensuring that children learn about and regularly debate whether, for example, it is plausible to think of Britain's people and institutions as liberal, conservative, secular, tolerant, and so on. Such regular debates illustrate how features of Britain, such as its people and institutions, are understood in a range of ways. Such regular debates also discourage children from just imbibing one conception and encourage them to think critically and to reject some views of Britain's people and institutions while endorsing others, so as to form their own conception of them.

Yet while a government should accept multiple conceptions of a polity, it must discourage conceptions in which citizens are, for example, of only one race or religion. Such conceptions do not suggest that cultural minorities are equal and normal. Instead, they can encourage, as I noted earlier, minorities to seem like'outsiders' despite their often being citizens, and can exacerbate their discrimination and exclusion. Any government that values the equal treatment of its citizens must discourage such conceptions, and in order to do so they can prohibit discrimination and promote race equality. Over time, this alters what many think is permissible in a polity, thus illustrating that their conceptions of 
it must have changed. A government can also declare the polity to be, inter alia, multicultural, as Canada did, and authorise school curricula to teach children about the different cultures in the polity. Thus, the policies of multiculturalism that some claim 'undermine' a national identity can be used to discourage exclusive conceptions of the polity and encourage inclusive ones (Uberoi, 2008, 2016).

At this point, some may think that Parekh is just one of those liberal nationalists who are also'multiculturalists' (Kymlicka, 2001a), as like them, Parekh advocates policies of multiculturalism and inclusive conceptions of a polity. But we should not use such similarities in a way that is inconsistent with how we use similarities between conservative and liberal nationalists. For example, both types of nationalists value a national culture and would restrict immigration to protect such a culture (Kymlicka, 2001b, p. 219; Scruton, 2006, p. 26), but we do not claim that liberal nationalists are just conservative nationalists, or vice versa. Instead, we classify liberal and conservative nationalists differently partly because, as I showed in the introduction to this article, such nationalists conceptualise ideas of nationhood differently, and some of them use their ideas of nationhood as part of a conservative doctrine while others use these ideas as part of a liberal doctrine. At least somewhat similarly, Parekh conceptualises the idea of national identity differently from liberal and conservative nationalists and uses this idea as part of a different doctrine in the following ways. ${ }^{7}$

Liberal and conservative nationalists might value people feeling part of and shaped by a nation or conceptions of a nation's identity (Miller, 1995, p. 18; Scruton, 2006, p. 15). Yet Parekh values people feeling part of and shaped by their polity and conceptions of a polity's identity. ${ }^{8}$ Equally, nationalist thinkers might argue that national identity is important to achieve conservative goals, like preserving traditional sources of authority (Smith, 2002, p. 17) or liberal goals such as aiding choice (Kymlicka, 1995, p. 83). Yet Parekh shows how a particular type of national identity helps to achieve the multiculturalist goal of intercultural learning by reducing fear of cultural difference and encouraging interaction regardless of such differences. Indeed, Parekh alone shows how national identity need not be part of a form of liberalism or conservativism. Instead, such an identity can be part of a form of multiculturalism that offers a 'vision' of what a culturally diverse polity can become.

\section{Criticisms}

An unconvinced critic might claim that, whatever else liberal nationalists are, they are liberals and nationalists, and Parekh is both. He is 'a liberal' as his vision for a polity contains liberal ideas (Kymlicka, 2001c), and a 'nationalist' as Parekh values national identity. Parekh thus seems like 'a liberal nationalist' and his approach does not seem distinct from a liberal nationalist's. I will thus now show that it is difficult to plausibly call Parekh'a liberal' or 'a nationalist' and it is thus also difficult to plausibly call Parekh a 'liberal nationalist'. 
It is difficult to plausibly call Parekh'a liberal'as doing so ignores the non-liberal aspects of his vision for a polity (Kelly, 2015, p. 31). For example, Parekh (2000d, p. 251) rejects the classical and contemporary liberal belief in which 'individuals are ultimate units of moral worth' (Kymlicka, 1989, p. 140). This is because this belief assumes reasons that are seldom given for when, why and how to individuate people as we cannot always do so as we may, for example, want to think of them as dependent children or parents. This liberal belief also refers to 'ultimate units of moral worth' but there is little or no attempt to say what 'units of moral worth' are, or how they are to be distinguished from 'ultimate' units of such worth. I also show elsewhere that Parekh's vision for a polity contains what he learned from non-liberal thinkers such as Oakeshott, Marx and Gandhi (Uberoi, 2015a). There are then various non-liberal features of Parekh's vision for a polity and we need plausible reasons to (1) ignore them (2) focus only on liberal features so as to (3) plausibly call Parekh 'a liberal'.

Those who suggest that Parekh is 'a liberal' (Kymlicka, 2001a, p. 132) do not offer any reasons to ignore the non-liberal aspects of his vision. They start at step 2 above and then they make another mistake: they note how Parekh's beliefs of equal participation, democratic representation, accountability and free speech are liberal beliefs even though conservatives and socialists have such beliefs too. They also claim that Parekh favours outcomes that seem liberal even though socialists and conservatives may use the aforementioned beliefs to justify similar outcomes to a liberal. ${ }^{9}$ In short, no scholar shows that Parekh conceptualises such beliefs in a particularly liberal way or uses such beliefs to justify outcomes that only a liberal would endorse. Not only then are (1) no reasons given to ignore the non-liberal aspects of Parekh's vision for a polity, but also (2) the features of Parekh's vision that seem liberal are not actually shown to be so. Hence, it is difficult to plausibly (3) claim that he is 'a liberal'.

Perhaps we can more modestly claim that Parekh is 'predominantly liberal'. Yet this assumes that Parekh can reject and not reformulate fundamental liberal beliefs about, for example, individuals and still be predominantly liberal. It also assumes that liberal aspects of his thought, in some way, dominate over non-liberal ones and no one has shown why this is true. Yet doing so is necessary to plausibly claim that Parekh is predominantly liberal. Thus, even this more modest version of the claim that Parekh is 'a liberal', seems unconvincing.

It is also difficult to plausibly call Parekh'a nationalist' as he does not defend the nationalism that is usually necessary to think of someone as a nationalist. Parekh thus does not argue that as a group is a nation it should have some level of 'self-rule' or that it should have its own state, as for example, a Scottish or Welsh nationalist might (Kedourie, 1998, p. 67). ${ }^{10}$ Nationalists also typically value nations (Gellner, 1983, p. 1; Kedourie, 1998, p. 67). Yet Parekh, we have seen, values national identity, not nations. And I showed earlier how Parekh argues that the ideas of national identity and nation are not as connected as some think. 
Indeed, unlike a nationalist, Parekh (1989, p. 191) shows why those groups who struggle for 'independence' may decide to call themselves something other than a nation, such as 'a group' or 'a community'. This is because they may not be the type of cultural community that is usually called a nation. And if this is true, then calling themselves a nation can make their struggle seem less convincing to themselves and to others whose support they need, which is partly why Gandhi often disagreed with those who called India a nation. Parekh is thus unlike those who are usually called 'liberal nationalists' as it is difficult to plausibly call him 'a liberal' or 'a nationalist'. It is thus also difficult to plausibly call Parekh 'a liberal nationalist'.

But I claim above that Parekh was influenced by Michael Oakeshott who was his teacher, and a conservative thinker. The critic might combine this with Parekh advocating the importance of national identity and now wonder if Parekh is a conservative nationalist. Note again that it is difficult to plausibly call Parekh 'a nationalist'. The critic is also assuming that Oakeshott influenced Parekh by making him politically conservative, and yet Oakeshott may have influenced Parekh in other ways; hence I show elsewhere how Oakeshott's early work on the nature of philosophy itself influenced Parekh's own conception of philosophy (Uberoi, 2015a).

Note also that Oakeshott (1991, p. 427) argued that those with a conservative 'disposition' do not offer 'visions' for what a polity should become, as such visions justify unnecessary 'change', not 'familiarity'. An Oakeshottian conservative would thus not offer a vision for a polity, but perhaps Parekh is politically conservative in a non-Oakeshottian way. The only argument that I know of that might support this suggestion comes from Paul Kelly (2001, p. 435). ${ }^{11}$ Kelly argues that Parekh conserves the values in a polity's constitution and laws by failing to identify the 'dominance, oppression and injustice' that these values may support. Yet, at most, Kelly shows that there is an important conservative aspect of Parekh's thought rather than that Parekh is 'a conservative'. Equally, Kelly has altered his claim so as to argue that this aspect of Parekh's thought does not 'preclude quite radical constitutional and social change' (Kelly, 2015, p. 50). Again it seems difficult to plausibly claim that Parekh is a conservative or a nationalist, thus it is strange to claim that he is a conservative nationalist.

Indeed, the distinctive nature of Parekh's thought is shown, in part, by how difficult it is to classify him as we do other political theorists who advocate national identity: as a liberal or conservative nationalist. This might encourage us try to classify Parekh in other ways, for example, as an advocate of 'multicultural nationalism'. Yet this implies that Parekh advocates nationalism and that he is a nationalist and neither, we have seen, seems true. Nor can we claim that Parekh advocates'multicultural nations', as he values national identity, not nations. And he shows why the two need not be as connected as some think. I have no unambiguous way to classify Parekh's work so I will simply summarise it: Parekh advocates the importance of national identity without advocating nations and 
nationalism or forms of liberalism and conservativism. This is because he advocates national identity as part of a form of multiculturalism that offers a vision of what a culturally diverse polity can become.

\section{Conclusion}

In this article, I have outlined Parekh's distinct way of thinking about national identity and I have shown that it is valuable as it contains insights into the nature and value of national identity. I will conclude by discussing three implications of his way of thinking about such an identity. The first implication is that Parekh avoids common criticisms that are often made of multiculturalists: that they care little for national identity, unity or interaction between different cultural groups. Parekh (2000a, p. 196) we have seen values all of these things. He thus shows why unity and national identity are important not only in any polity but especially in one that aims for culturally different people to interact so as to learn from one another.

In response, some may say that Parekh endorses policies of multiculturalism which are divisive and lead to residential segregation instead of interaction between culturally different people. But it is unclear why the policies referred to above of prohibiting discrimination, promoting race equality, declaring a polity to be multicultural and teaching school children about different cultural groups in the polity are necessarily divisive. And it is noticeable that scholars who examine residential segregation discuss drivers such as higher birth rates among some groups, lower death rates among others, 'white flight' and affordable accommodation, not policies of multiculturalism (Peach 2009). Some might still say that schools that teach children of only one faith, or public services that are provided in different languages must be divisive. I am unaware of any evidence to support such claims, but suppose such evidence exists and that it is compelling. This merely suggests that these specific policies are divisive but not that all policies of multiculturalism are, or that the ones that Parekh endorses are.

A second implication is that Parekh avoids the obvious ways in which conservative and liberal nationalists can be criticised. Thus, conservative nationalists suggest that a national identity can convey 'life's meaning' (Scruton, 1990, p. 310) but Parekh (1999, p. 310) rejects this notion as it is asserted, not argued and defended. And it is unclear why, for example, England's, Britain's or America's identity, or feeling English, British or American, would convey the meaning of life or reconcile a person to the world in Hegel's famous sense.

Equally, for Parekh, national identity need not cultivate the 'solidarity', 'obligation' and 'trust' that people allegedly require to redistribute their income as liberal nationalists claim (Miller, 1995; pp. 83, 91-93; Miller, 2016, p. 28). This is because liberal nationalists have said little, as yet, to explain exactly what 'solidarity', 'obligation' and 'trust' are or why it is national identity that stimulates these things rather than other stimuli. ${ }^{12}$ Instead, liberal nationalists show us 
how to conceive national identity and note that whether such identities aid the redistribution of income is an empirical issue. Yet empirical evidence does not prove or disprove their claim, as liberal nationalists admit (Kymlicka 2015, p. 8; Miller, 2016, p. 28; Miller \& Ali, 2014, pp. 240, 254). Parekh (1999, 2012) has thus long criticised this way of arguing that national identity is important, and he argues for its importance differently.

Thus, Parekh's way of thinking about national identity is not vulnerable to obvious ways in which multiculturalists, liberal and conservative nationalist can be criticised. There are, no doubt, other ways to criticise such thinkers and Parekh's way of thinking about national identity may be vulnerable to other such criticisms. But to find out if it is, political theorists can no longer ignore Parekh's way of thinking about such an identity and as I noted in the introduction of this article, they often do. This brings me to the third implication: as Parekh's way of thinking about national identity is distinct, valuable and not vulnerable to obvious criticisms, it should be studied more and some obvious ways to do so are as follows.

To aid our understanding of the nature of Parekh's thought regarding national identity we can examine how historically novel it is by comparing it to how previous thinkers have discussed the identity of a polity and national character. To aid our understanding of the history of Parekh's way of thinking about national identity, we can examine Oakeshott's (2006, p. 411) work as he did not value nations and nationalism either. But this did not deter Oakeshott (2004, p. 176) from valuing the concept of national character, just as it does not deter Parekh from valuing the concept of national identity. We could also examine the influence of Parekh's way of thinking about national identity on other multiculturalists (Modood, 2014; Uberoi, 2007) ${ }^{13}$ and the reports of commissions that Parekh was part of (Uberoi, 2015b). Finally, we can examine the implications of Parekh's way of thinking about national identity for immigration, citizenship and foreign policy and those seeking secession, all of which require us to think about national identity. This would improve our knowledge of the nature, history, influence and implications of Parekh's way of thinking about national identity.

This study can then act as the basis of a larger comparison between Parekh's approach and the nature, history, influence and implications of liberal and conservative nationalism (Miller, 2009). From this comparison we can discern different insights from the different ways of thinking about national identity and what each approach can learn from the others. Using this comparative study, we can also examine which ways of thinking about national identity are vulnerable to post-national and cosmopolitan criticisms, and which may not be (Benhabib, 2008; Müller, 2007). Such a comparative study would also provide insights for policy-makers into the policy areas that I mention above, which require us to think about national identity.

Yet scholars who conduct such investigations must avoid two assumptions. First, they must not assume that liberal and conservative nationalism are the 
only, or the most plausible way, in which political theorists advocate national identity (Crowder, 2013, pp. 83-85). Second, such scholars must also not assume that multiculturalists do not advocate national identity (Barry, 2000, p. 77). Indeed, both assumptions should now seem implausible as I have, I hope, shown that a multiculturalist has devised a way of thinking about national identity that is distinct, valuable, not vulnerable to obvious criticisms and worthy of further research.

\section{Notes}

1. The thinkers I am referring to also exclude Maurizio Viroli (1995) and Seyla Benhabib (2008) who discuss how older ideas of 'patriotism' or'cosmopolitanism' are more defensible than ideas of nationhood.

2. Some may think of Kymlicka as a liberal multiculturalist and may thus wonder why I refer to him as a liberal nationalist. I do so for four reasons. First, Kymlicka $(2015$, p. 6) at times refers to himself as a liberal nationalist and Kymlicka (1995, p. $49,75,145)$ is explicit about being a liberal and a nationalist. Second, Kymlicka $(1995$, p. 80, 83) pioneered the liberal nationalist argument that choice requires something to choose with which, for Kymlicka, is a national culture. Third, Kymlicka (1995, p. 75; 2001a, p. 20; 2002, p.254) endorses well known liberal nationalist ideas such as national identity helps to foster the solidarity that a welfare state requires. Finally, Kymlicka (2001a, p. 54-58) brilliantly distinguishes nine features of liberal nation building from illiberal nationalism and endorses liberal nation-building.

3. The difference between a polity and a nation seems to be this: if a polity did not have legal and political norms, values, beliefs and institutions it would no longer be a polity. But if a nation such as, for example, England, does not have legal and political norms, values, beliefs and institutions, it does not stop being a nation. A nation, therefore, does not need such legal and political norms values and beliefs to exist but a polity does. I do not deny that members of a nation often seek to have their own legal and political norms, values, beliefs and institutions so as to be an independent nation, and they may even refer to this independent nation somewhat poetically as a 'true' or a 'real' nation. But I do not think that nations need their own legal and political norms values and beliefs just to be a nation or the idea of a nation seeking independence would seem very strange.

4. See Bechoffer and McCrone (2007, p. 253), Parekh (1989, p. 191) and Uberoi (2015b, p. 517). It is noticeable that in Parekh's $(2015$, p. 55) latest book he refers to the national anthem, national flag as symbols of only the 'state'.

5. Some may find this term 'vision'strange. Yet Sheldon Wolin $(2004$, p. 18) famously showed that political philosophers can offer a political vision rather like a'religious or artistic vision', which 'imaginatively' depicts what a polity might become. It is also common to think of multiculturalists in Britain as offering such a vision (See Modood, 2010, p. 6).

6. No doubt some conceptions of a polity will focus on disputes, but such disputes are envisaged as existing within a group. And just as disputes among family members, friends and co-religionists need not stop them assuming or thinking that they are a group, the same is often true for members of a polity.

7. Parekh (2000b, p. 336) denies that his understanding of multiculturalism is a 'doctrine', but by a doctrine I simply mean a system of thought and I have 
struggled to identify another shorthand way of describing this idea, as other terms such as 'ideology' would also be rejected by Parekh (2000b, p. 340).

8. Over a long period Parekh (1986, p. 37, 1999, p. 309) would often criticise nations while elsewhere advocating the importance of national identity (Parekh, 1989, p. 71, 1994, p. 505, 2000a, p. 219). The criticism of nations stopped seemingly because of Tariq Modood's (Uberoi, 2015b, p. 518) influence on Parekh, but even when Parekh criticised nations at the same time as advocating national identity, Parekh was not necessarily being inconsistent. This is because Parekh had noticed how the concept of national identity today does not necessarily entail the concept of nation.

9. The 'boundary problem' between liberalism and other doctrines is now often discussed (see Freeden, 1998, chapter 7) but one response is that there are liberal beliefs in conservatism and socialism. Yet this just raises questions about why such beliefs should be thought of as liberal when they are common to other doctrines, and why is an advocate of beliefs that are common to others doctrines, like Parekh, necessarily a liberal?

10. Parekh (2011, p. 33) has certainly justified on one occasion granting groups greater political autonomy in a federal political structure because doing so can reduce conflict, improve democracy, prevent injustice and so on. But he does not argue for this as a nationalist would, as he does not argue that just because a group is a nation it requires some level of self-determination (Miller, 1995, p. 83).

11. Of course Kelly does not think of this as a non-Oakeshottian component of Parekh's thought.

12. This is perhaps why David Miller thinks that there is still a need to clarify the concept of solidarity and has begun to do so. See. D. Miller, 'Solidarity and its Sources' in K. Banting and W. Kymlicka, The Stains of Commitment, Oxford University Press, 2017.

13. Parekh's influence on Modood is not one-way, as I have shown elsewhere that Modood influenced how Parekh came to think about national identities being more inclusive too in Uberoi (2015b, p. 518).

\section{Acknowledgements}

I am grateful to the two independent reviewers, Bhikhu Parekh, David Miller, Andrew Mason and Elise Uberoi for their feedback. I am also grateful to Tariq Modood and Geoffrey Brahm Levey as section two of this piece became clearer in my mind through a conversation that we had at the Max Planck Institute, Halle. I am also grateful to Mark Bevir, Richard Ashcroft, Per Mouritsen and Nils Holtug for inviting me to Berkeley, Aarhus and Copenhagen where I presented early versions of this piece and benefited immensely from their comments.

\section{Disclosure statement}

No potential conflict of interest was reported by the author.

\section{Funding}

This work was supported by the British Academy. 


\section{Notes on contributor}

Varun Uberoi is Senior Lecturer in Political Theory and Public Policy, Department of Politics and History, Brunel University, London, UK

\section{References}

Abizadeh, A. (2002). Does liberal democracy presuppose a cultural nation? Four arguments American Political Science Review, 96(03), 495-509.

Barry, B. (2001). Culture and equality. Cambridge: Polity.

Bechhofer, F. \& McCrone, D. (2007). Being british: A crises of identity. Political Quarterly, $78(2), 251-260$.

Benhabib, S. (2008). Another cosmopolitanism. Oxford: Oxford University Press.

Berlin, I. (2003). The bent twig: On the rise of nationalism In The crooked timber of humanity. London: Pimlico.

Burke, E. (1996). Reflection on the revolutions in France. In Modern political thought: Readings from Machiavelli to Nietzsche. Oxford: Hackett.

Canovan, M. (1996). Nationhood and political theory. Cheltenham: Edward Elgar Press.

Cohen, G. A. (1979). Karl Marx's theory of history: A defence. Oxford: Oxford University Press.

Crowder, G. (2013). Theories of multiculturalism. Cambridge: Polity.

Freeden, M. (1998). Ideologies and political theory. Oxford: Oxford University Press.

Gellner, E. (1983). Nations and nationalism. Oxford: Blackwell.

Goodhart, D. (2013). The British dream: Successes and failures of post-war immigration. London: Atlantic Books.

Habermas, J. (1998). The inclusion of the other. Cambridge, MA: MIT Press.

Kant, I. (1929). Selections. London: Charles Schreiber.

Kedourie, E. (1998). Nationalism. Oxford: Blackwell.

Kelly, P. (2001). Dangerous liaisons-parekh and oakeshottian multiculturalism. Political Quarterly, 72(4), 428-436.

Kelly, P. (2015). Situating Parekh's multiculturalism: Bhikhu Parekh and twentieth-century British political theory. In V. Uberoi \& T. Modood (Eds.), Multiculturalism rethought (pp. 29-54). Edinburgh: Edinburgh University Press.

Kymlicka, W. (1989). Liberalism, community and culture. Oxford: Clarendon Press.

Kymlicka, W. (1995). Multicultural citizenship. Oxford: Clarendon Press.

Kymlicka, W. (2001a). Can liberal pluralism be exported? Oxford: Oxford University Press.

Kymlicka, W. (2001b). Politics in the vernacular. Oxford: Oxford University Press.

Kymlicka, W. (2001c). Liberalism dialogue and multiculturalism. Ethnicities, 1, 1.

Kymlicka, W. (2002). Contemporary political philosophy. Oxford: Oxford University Press.

Kymlicka, W. (2015). Solidarity in diverse societies: Beyond neoliberal multiculturalism and welfare chauvinism'. Comparative Migration Studies, 3(17), 11-19.

Mason, A. (2012). Living together as equals: The demands of citizenship. Oxford: Oxford University Press.

Mill, J. S. (1991). On Liberty and other essays. Oxford: Oxford University Press.

Miller, D. (1995). On nationality. Oxford: Clarendon Press.

Miller, D. (2001). Citizenship and national identity. Cambridge: Polity Press.

Miller, D. (2009). Nationalism. In J. Dryzek, B. Honig, \& A. Phillips (Eds.), The Oxford Handbook of Political Theory. Oxford: Oxford University Press.

Miller, D. (2016). Strangers in our midst. Cambridge, MA: Harvard University Press. 
Miller, D., \& Ali, S. (2014). Testing the national identity argument. European Political Science Review, 6(02), 237-259.

Modood, T. (1992). Not easy being british. London: Trentham Books.

Modood, T. (2001). Their liberalism and our multiculturalism? The British Journal of Politics and International Relations, 3(2), 245-257.

Modood, T. (2010). Still not easy being British. London: Trentham Books.

Modood, T. (2014). Multiculturalism and Britishness: Provocations, hostilities and advances. In R. Garbaye \& P. Schnapper (Eds.), The Politics of Ethnic Diversity in the British Isles (pp. 21-37). Basingstoke: Palgrave Macmillan.

Müller, J. W. (2007). Constitutional patriotism. Princeton, NJ: Princeton University Press.

Oakeshott, M. (1991). Being conservative. In Rationalism in politics. IN: Liberty Fund.

Oakeshott, M. (2004). On peace with Germany. In What is history and other essays. Exeter: Imprint Publishing.

Oakeshott, M. (2006). Lectures in the history of political thought. Exeter: Imprint Publishing.

Parekh, B. (1974). Postscript. In B. Parekh (Ed.), Colour, culture and consciousness: Immigrant intellectuals in Britain (pp. 220-246). London: George Allen \& Unwin Ltd.

Parekh, B. (1981). Hannah Arendt and the search for a new political philosophy. Atlantic Highlands, NJ: Humanities Press

Parekh, B. (1982). Marx's theory of ideology. London: Croom Helm.

Parekh, B. (1986). The 'new right' and the politics of nationhood. In N. Deakin (Ed.), The new right: Image and reality (p. 39). London: Runnymede Trust.

Parekh, B. (1989). Ghandi's political philosophy: A critical examination. Basingstoke: Macmillan.

Parekh, B. (1990). Britain and the social logic of pluralism. In Commission for racial equality (Ed.), Britain: A plural society. Report of a seminar (pp. 58-76). London: Commission for Racial Equality.

Parekh, B. (1994). Discourses on national identity. Political studies, XLII, 492-504.

Parekh, B. (1995). The concept of national identity. New Community, 21(2), 244-268.

Parekh, B. (1996). Citizenship and political obligation. In P. King (Ed.), Socialism and the commonGood (pp. 259-289). London: Frank Cass.

Parekh, B. (1999). The incoherence of nationalism. In R. Beiner (Ed.), Theorizing nationalism (pp. 295-327). New York, NY: State University of New York Press.

Parekh, B. (2000a). Rethinking multiculturalism. Basingstoke: Macmillan.

Parekh, B. (2000b). Defining British identity. Political Quarterly, 71(1), 1-13.

Parekh, B. (2000c). 'Preface', Parekh, Report. London: Profile Books.

Parekh, B. (2000d). Theorizing political theory. In N. O'Sullivan (Ed.), Political theory in transition (pp. 242-259). London: Routledge.

Parekh, B. (2008). A new politics of identity: Political principles for an interdependent world. Basingstoke: Palgrave Macmillan.

Parekh, B. (2009). Being British. In A. Gamble \&T. Wright (Eds.), Britishness perspectives on the British question (pp. 32-41). Oxford: Wiley.

Parekh, B. (2011). Liberal democracy and national minorities. In F. Requejo \& M. Caminal (Eds.), Political liberalism and plurinational democracies (pp. 31-43). London: Routledge.

Parekh, B. (2012). Multicultural society and the welfare state. In J. Connelly \& J. Hayward (Eds.), The Withering of the Welfare State (pp. 52-68). Basingstoke: Palgrave Macmillan.

Parekh, B. (2015). Debating india. Oxford: Oxford University Press.

Parfit, D. (1987). Reasons and persons. Oxford: Oxford University Press.

Peach, C. (2009). Slippery segregation: Discovering or manufacturing ghettoes. Journal of Ethnic and Migration Studies, 35(9), 1381-1395.

Renan, E. (2001). What is a nation? In V. Pecora (Ed.), Nations and identities: Classic readings (pp. 162-176). Oxford: Blackwell. 
Scruton, R. (1990). The Philosopher on Dover Beach: Essays. Manchester, NH: Carcanet. Scruton, R. (2006). Arguments for conservatism: A political philosophy. London: Continuum. Scruton, R. (2014). How to be a conservative. London: Bloomsbury.

Smith, A. (2002). Nationalism. Cambridge: Polity.

Sorabji, R. (2006). Self-ancient and modern insights about individuality, life and death. Oxford: Oxford University Press.

Tamir, Y. (1993). Liberal nationalism. Princeton, NJ: Princeton University Press.

Uberoi, V. (2007). Social unity in Britain. Journal of Ethnic and Migration Studies, 33(1), $141-157$.

Uberoi, V. (2008). Do policies of multiculturalism undermine national identities? Political Quarterly, 79(3), 404-417.

Uberoi, V. (2015a). Introduction. In V. Uberoi \&T. Modood (Eds.), Multiculturalism rethought (pp. 1-25). Edinburgh: Edinburgh University Press.

Uberoi, V. (2015b). The 'Parekh Report' - National identities without nations and nationalism. Ethnicities, 15(4), 509-526.

Uberoi, V. (2016). Legislating multiculturalism and nationhood- The Canadian multiculturalism act. Canadian Journal of Political Science, 49(2), 267-287.

Viroli, M. (1995). For love of country. Oxford: Oxford University Press.

Wolin, S. (2004). Politics and vision. Princeton, NJ: Princeton University Press.

Yack, B. (2012). Nationalism and the moral psychology of community. Chicago, IL: University of Chicago Press. 